Article

\title{
Investigating Influence of Hydrological Regime on Organic Matters Characteristic in a Korean Watershed
}

\author{
SangSoo Baek ${ }^{1}$, Hyuk Lee ${ }^{2}$, Jongkwan Park ${ }^{1, *}$ and Kyung Hwa Cho ${ }^{1, *}$ \\ 1 School of Urban and Environmental Engineering, Ulsan National Institute of Science and Technology, \\ Ulsan 44919, Korea; kbcqr@unist.ac.kr \\ 2 Water Quality Assessment Research Division, National Institute of Environmental Research, Environmental \\ Research Complex, Incheon 22689, Korea; ehyuk72@korea.kr \\ * $\quad$ Correspondence: jkpark@unist.ac.kr (J.P.); khcho@unist.ac.kr (K.H.C.); Tel.: +82-52-217-2886 (J.P.); \\ +82-52-217-2829 (K.H.C.); Fax: +82-52-217-2819 (J.P. \& K.H.C.)
}

Received: 3 February 2019; Accepted: 7 March 2019; Published: 12 March 2019

\begin{abstract}
Source tracking of dissolved organic matter (DOM) is important to manage water quality in rivers. However, it is difficult to find the source of this DOM because various DOMs can be added from the river watershed. Moreover, the DOM composition can be changed due to environmental conditions. This study investigated the change of organic matter characteristics in the Taewha River of Ulsan City, Korea, before and after rainfall. A Soil and Water Assessment Tool (SWAT) was used to simulate water flow from various sources, and dissolved organic matter characterization was conducted in terms of molecular size distribution, hydrophobicity, fluorescence excitation and emission, and molecular composition. From the results, it was found that lateral flow transported hydrophobic and large-molecule organic matter after rainfall. According to the orbitrap mass spectrometer analysis, the major molecular compound of the DOM was lignin. Coupling the SWAT model with organic matter characterization was an effective approach to find sources of DOM in river.
\end{abstract}

Keywords: dissolved organic matter (DOM); soil and water assessment tool (SWAT); orbitrap mass spectrometry; fluorescence excitation emission matrix (EEM)

\section{Introduction}

Dissolved organic matter (DOM) plays an important role in aquatic environments. It can be a nutrient source for microorganisms and a carrier for heavy metals and pollutants [1-3]. In addition, ubiquitous distribution and heterogeneity of DOM has become an active research topic in order to understand its origin and reactivity [4-6].

DOM has different characteristics in terms of physical, chemical, and biological properties based on its origin [7]. In general, terrestrial DOM, originating from plant litter and soil humus, contains mostly carbohydrates and lignin while autochthonous DOM, derived from algae and macrophyte, has a relatively high percentage of protein [8,9]. However, characteristics of DOM cannot be classified into two groups (terrestrial and autochthonous) because DOM is affected by various environmental factors such as source material, microbial community, and temperature [10-12].

Rainfall is one of the environmental factors responsible for changing the concentration and characteristics of DOM in surface water. Numerous studies have reported the relationship between hydrological conditions and organic matter properties in a river during rainfall events. Rainfall-runoff transports a large amount of terrestrial organic matter, including lignin and humic substances, to rivers $[13,14]$. As a result of the inflow, molecular weight and aromaticity of DOM are increased and protein-like substances are decreased $[15,16]$. However, these studies have focused mainly on the 
change of DOM properties in river water during rainfall rather than the origins of added DOM that results in the property changes.

Since migration of DOM is influenced by the water flow, an understanding of hydrologic flows before and after rainfall events is useful information for investigating DOM characteristics in a river. Various hydrological models have been applied to estimate water flows in a river [17-19], and, among the models, the Soil and Water Assessment Tool (SWAT) has been used in various environments relating to hydrology [20-22].

SWAT is a watershed-scale model for simulating hydrologic processes and analyzing the influence of land management practices [23,24]. This is a physics-based model, suitable for large basins [25]. The advantages of using the SWAT model are that it simulates surface runoff, lateral flow, and total runoff depending on the soil moisture, stream properties, and weather $[22,26]$. The information of each flow helps to characterize the targeted water bodies such as a river or lake $[27,28]$. This study aims to characterize DOM for source tracking after rainfall, by applying the SWAT model. We characterized DOM with various analysis tools and were encouraged by the analyzed DOM properties and the simulated hydrologic result to show different sources of DOMs after the rainfall event.

\section{Materials and Methods}

\subsection{Sampling Sites}

Ulsan City is in the northeastern part of Gyeongsangnam-do, a southern province of South Korea. The area of the city is $1061.1 \mathrm{~km}^{2}$, while the Taehwa River has a length of $47.54 \mathrm{~km}$ and flows from west to east across the urban area $\left(129^{\circ} 0^{\prime} \mathrm{E}-129^{\circ} 25^{\prime} \mathrm{E}, 35^{\circ} 27^{\prime} \mathrm{N}-35^{\circ} 45^{\prime} \mathrm{N}\right.$ ) (Figure 1). About $63 \%$ is covered by forest, $15 \%$ is used as an urban area, $13 \%$ is an agricultural area, and the rest is open space, water, and grassland. The climate of Ulsan City is temperate with slightly hot, humid summers, and cold, dry winters [29]. The average temperature and precipitation are $14.1^{\circ} \mathrm{C}$ and $1277.1 \mathrm{~mm}$, respectively, from 1981 to 2010.

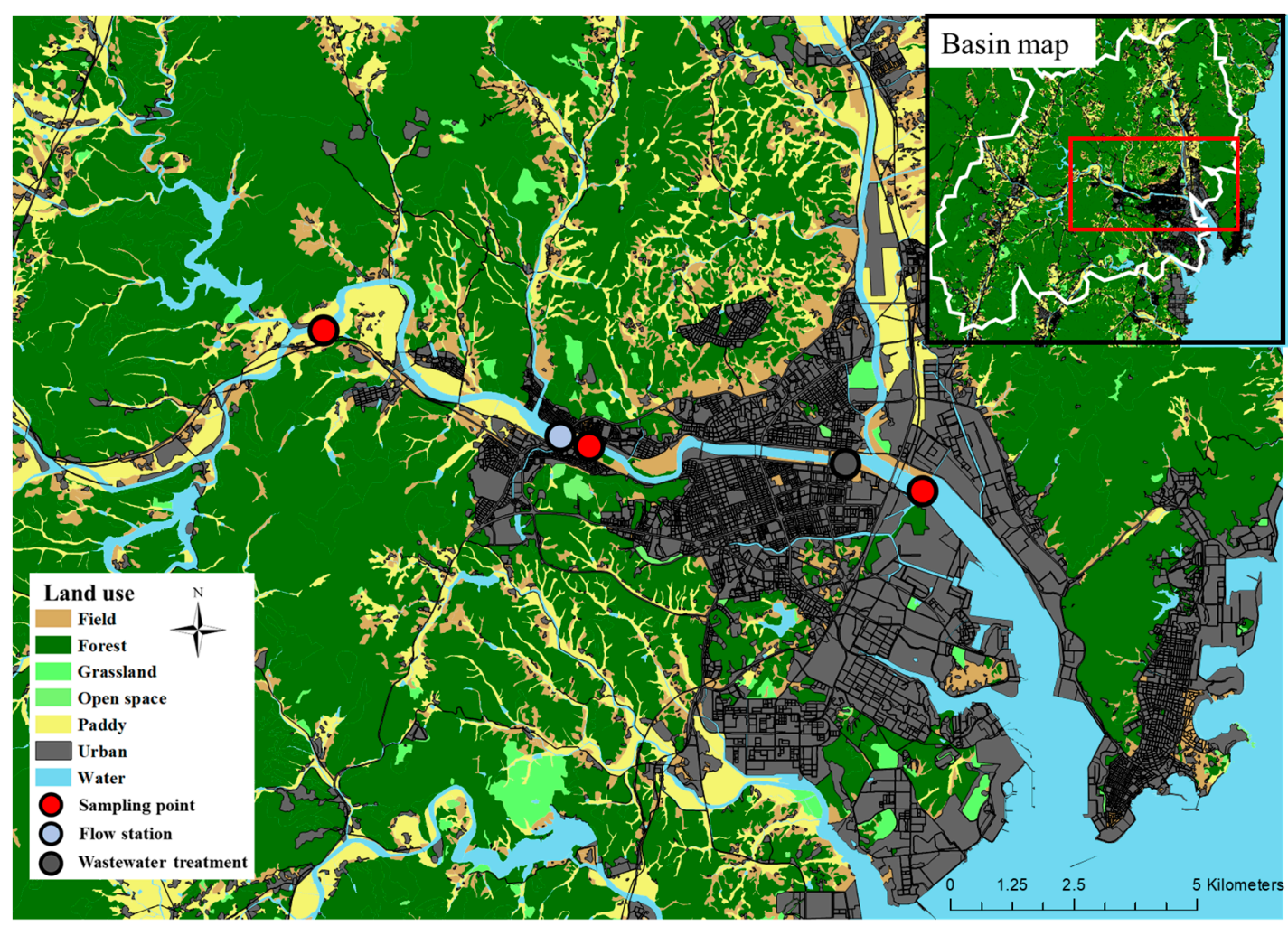

Figure 1. Sampling points in the Taewha River in Ulsan City, Korea. 
We took water samples from three sites before and after rainfall. The before-rainfall sampling was conducted when the river had seven days of antecedent dry period. This sample was considered as a low flow-conditions water sample. The after-rainfall sampling was carried out $12 \mathrm{~h}$ after rainfall, but within $24 \mathrm{~h}$ to reduce the effect of overland flow and rainfall on the river. This sample was considered as a water sample containing DOMs with different sources. For comparing the effect of rainfall intensity on DOM composition, the samplings were collected twice in heavy rainfall and light rainfall. The wastewater treatment and tidal processes did not affect the sampling sites because the effluent of the wastewater treatment plant was discharged into another small stream, and the samplings were carried at low tide.

\subsection{Water Quality Analysis}

The water samples were manually collected from 11:00 a.m. to 3:00 p.m. and placed in an icebox with ice. The samples were stored in a 12-L polyethylene bottle; the water samples were analyzed within $24 \mathrm{~h}$ in the laboratory. Conductivity was measured with an Orion conductivity meter (Orion 4 star, Thermo, Cleveland, OH, USA). The water samples were filtered through a $0.45-\mu \mathrm{m}$ micro filter (Polycap capsule filter 36AS, Whatman Corp., Little Chalfont, UK). Concentrations of dissolved organic carbon (DOC) were measured using catalytic combustion based on total organic carbon analyzer (TOC-V CPH/CPN, Shimadzu, Kyoto, Japan). Molecular weight distribution was estimated using a high-pressure liquid chromatography (HPLC) system (HPLC, Shimadzu, Japan), and HPLC equipped with a size exclusion chromatography (SEC) column (Protein-Pak 125, Waters, Milford, MA, USA) was used to calculate the molecular weight. The analyses were performed at $254 \mathrm{~nm}$ using a UV detector (SPD-10A VP, Shimadzu Co., Japan). The eluent consisted of a phosphate and sodium chloride buffer to retain a $\mathrm{pH}$ of 6.8 and an ionic strength of $0.1 \mathrm{M}$ (5.4 mM sodium phosphate, $1.6 \mathrm{mM}$ disodium hydrogen phosphate, and $93.0 \mathrm{mM}$ sodium chloride). There was $200 \mu \mathrm{L}$ of the sample injected into the column and the eluent flow rate was $0.7 \mathrm{~mL} / \mathrm{min}$. Hydrophobicity of the sample was estimated by the XAD resin fractionation method. The XAD-8/4 resins were used for separating hydrophobic NOM (XAD-8 absorbable), transphilic NOM (XAD-4 absorbable) and hydrophilic NOM (neither XAD-8 nor XAD-4 absorbable) constituents. XAD-8/4 resins were cleaned with $0.1 \mathrm{~N} \mathrm{NaOH}, 0.1 \mathrm{~N} \mathrm{HCl}$, and DI water. All samples were acidified to $\mathrm{pH} 2.0$ before this experiment. The 3D Excitation emission matrix (EEM) fluorescence spectra were measured by an F-2500 fluorescence spectrometer (Hitachi Co., Tokyo, Japan). Ranges of the emission and excitation were $220-500 \mathrm{~nm}$ at $10 \mathrm{~nm}$ intervals. Silt widths of the emission and excitation were set to a $5 \mathrm{~nm}$ bandwidth; with a $3000 \mathrm{~nm} / \mathrm{min}$ scan speed. The EEM results were characterized by the fluorescence regional integration (FRI) method [30]. FRI divided the result into five regions based on the excitation and emission wavelength: (1) aromatic proteins group at region I and II where excitation wavelength is lower than $250 \mathrm{~nm}$ and emission wave length is lower than $350 \mathrm{~nm}$, (2) fulvic acid organic group at region III where excitation wavelength is lower than $250 \mathrm{~nm}$ and emission wavelength is lower than $350 \mathrm{~nm}$, (3) soluble microbial byproduct-like material group originating from microbial activity at region IV where excitation wavelength is lower than $280 \mathrm{~nm}$ and emission wavelength is lower than $380 \mathrm{~nm}$, (4) humic acid-like organic group at region $\mathrm{V}$ where excitation wavelength is greater than $280 \mathrm{~nm}$ and emission wavelength is greater than $380 \mathrm{~nm}$. All EEMs subtracted the water Raman band to reduce instrument bias. The EEM data were plotted using MATLAB software (MathWorks, Inc., Natick, MA, USA).

\subsection{Molecular Composition Analysis of DOM}

To increase analytical resolution, solid phase extraction (SPE) was conducted as a sample pretreatment step. A mixed SPE cartridge was used to improve the sorption efficiency of DOM in water. The cartridge consisted of HLB (Oasis, Waters, USA), ENV+ (International Sorbent Technology, Hengoed, UK), Strata X-AW, and X-CW (Phenomenx, Cheshire, UK). The SPE experiment was conducted according to Jeon et al. [31]. $5 \mathrm{~mL}$ of methanol flowed to the cartridge for conditioning, and $10 \mathrm{~mL}$ of DI water cleaned the cartridge. After the steps, $1000 \mathrm{~mL}$ of sample was loaded into the 
cartridge with $15 \mathrm{~mL} / \mathrm{min}$ using a vacuum pump. Then, the absorbed DOM was extracted with $6 \mathrm{~mL}$ ethyl acetate/methanol (50:50 $\mathrm{v} / \mathrm{v})$ with $0.5 \%$ ammonia and $3 \mathrm{~mL}$ of ethyl acetate/methanol (50:50 $v / v$ ) with $1.7 \%$ formic acid following cartridge drying with nitrogen gas. The extracted sample was evaporated at $35^{\circ} \mathrm{C}$ with nitrogen gas until the sample volume was reduced to $1 \mathrm{~mL}$.

After the SPE pretreatment step, the unknown screening analyses were performed by the Ultimate 300 UPLC system (Thermo Fisher Scientific, San Jose, CA, USA) coupled to QExactive plus Orbitrap mass spectrometry (Thermo Fisher Scientific, San Jose, CA, USA) equipped with a heated electrospray interface (HESI) in both positive and negative modes. Before the unknown screening analysis, this instrument was calibrated by positive and negative calibration solutions (Proteomass ESI, Sigma-Aldrich, St. Louis, MO, USA). There was $200 \mu \mathrm{L}$ of the sample analyzed with a methanol mobile phase. The $\mathrm{m} / \mathrm{z}$ scan range was from 100 to 2000. The HESI operational conditions were as follows: sheath gas flow $(45 \mathrm{~L} / \mathrm{min})$, capillary temperature $\left(320^{\circ} \mathrm{C}\right)$, spray voltage $(3800 \mathrm{~V} / 3000 \mathrm{~V})$, auxiliary gas pressure (10 arbitrary units), and ion sweep gas ( 2 arbitrary units).

Molecular formulas were calculated using compound identification algorithms [32,33] on MATLAB software (MathWorks, Inc.) considering the following elements: $\mathrm{C}, \mathrm{H}, \mathrm{O}, \mathrm{N}$, and S. Elemental compositions of molecules were converted to hydrogen to carbon ratio $(\mathrm{H} / \mathrm{C})$, oxygen to carbon ratio $(\mathrm{O} / \mathrm{C})$. To illustrate the possible type of compounds, the ratios of $\mathrm{H} / \mathrm{C}$ and $\mathrm{O} / \mathrm{C}$ for each formula were plotted using van Krevelen diagrams [34]. Identified formulae were classified into four groups: (1) $\mathrm{CHO}$, (2) CHON, (3) CHOS, and (4) CHONS.

\subsection{The SWAT Model Setup and Input Parameters}

The SWAT model is a continuous, semi-distributed watershed simulator on a daily time step [22,35]. This model is developed to analyze the impact of the hydrological cycle including surface runoff, evapotranspiration, and infiltration in a watershed [22]. This model can also estimate major hydrologic components including surface runoff, groundwater, and lateral flow [35]. The SWAT model uses geospatial and meteorological information, including digital elevation maps (DEM), land-use maps, soil-properties maps, and meteorological data. Online Water Resource Management Information System (WAMIS; http:/ / wamis.go.kr) provided a DEM and land-use map for the Taehwa River. Soil information was obtained from the Korean Soil Information System (http:/ / soil.rda.go.kr). The meteorological data (i.e., air temperature, relative humidity, rainfall, solar radiation, and wind speed) for a period of 12 y (2005-2016) were downloaded from the Meteorological Information Portal Service System (http:/ / data/kma/go.kr). The watershed delineation produced 19 sub-basins and 125 hydrologic response units. The simulation period of 12 y from January 2005 to December 2016 was set up for the watershed (spin-up period: 2005-2006, calibration period: 2007-2016). We adopted the Hargreaves method for calculating potential evapotranspiration. This method considers the temporal variation of temperature and precipitation [36]. We generated the daily model simulation.

After the boundary conditions of the SWAT model were established, sensitivity analysis and calibration of the daily flow was performed using Sequential Uncertainty Fitting version-2 171 (SUFI-2) in the SWAT calibration and uncertainty procedure (SWAT-CUP).

\section{Results and Discussion}

\subsection{SWAT Model Result}

Figure 2 shows the calibrated and validated results of the hydrologic module of the SWAT model and Table 1 shows the calibrated parameter set. The Nash-Sutcliffe Efficiency coefficient (NSE) was applied to evaluate the SWAT model. NSE can determine whether the model is satisfactory or unsatisfactory, and the model is considered acceptable, or satisfactory, when the calculated values of NSE are greater than 0.5 [37]. The calibrated SWAT model showed an acceptable performance during calibration and validation periods because the NSE values were greater than 0.5 for both periods. 


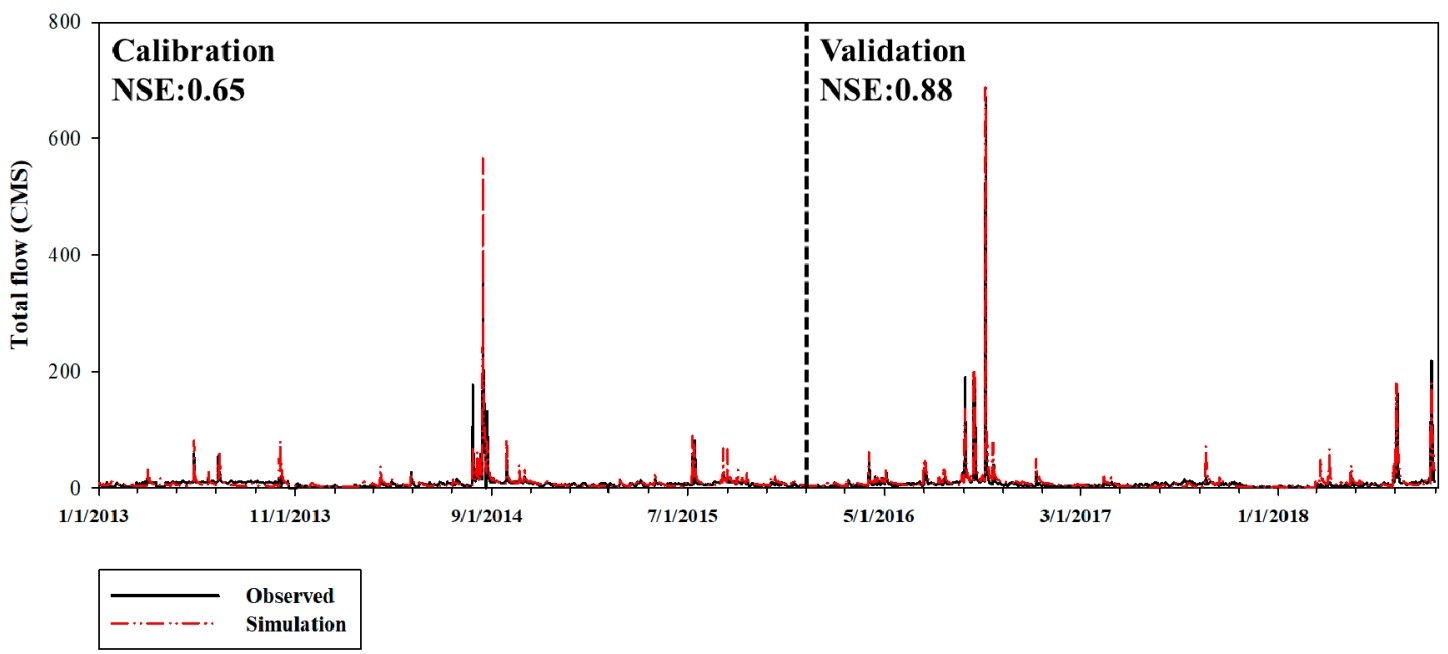

Figure 2. Observed and simulated total flow from January 2013 to September 2018.

Table 1. Calibrated parameter set.

\begin{tabular}{clc}
\hline Parameter & \multicolumn{1}{c}{ Desrctiption } & Value \\
\hline Alpha_Bf & Baseflow recession constant & 0.954 \\
Ch_N2 & Manning coefficent for channel & 0.2029 \\
Cn2 & SCS runoff curve number & 0.015 \\
Ch_K2 & Effective hydraulic conducitivbity in main channel alluvium & 126 \\
Rchrg_dp & Deep aquifer percolation fraction & 0.085 \\
Sol_Awc & Available water capacity of soil layer & -0.375 \\
Epco & Plant uptake compensation factor & 0.22 \\
Biomix & Biological mixing efficiency & 0.805 \\
Slsubbsn & Average slope length & 135 \\
Esco & Soil evaporation compensation factor & 0.285 \\
\hline
\end{tabular}

Figure 3 shows the simulated total runoff, surface runoff, and lateral flow, and ground water flow during the sampling period. Table 2 shows characteristics of rainfall events. Event 1 had heavy rainfall $(254 \mathrm{~mm})$ while Event 2 had a relatively lower amount of rainfall $(47.2 \mathrm{~mm})$. In both Events, the total runoff increased as the amount of rainfall increased (Figure 3a). Additionally, the simulated surface runoff, lateral flow, and ground water flow in Event 1 were larger than in Event 2. A large amount of surface runoff occurred when the rainfall amount is high, and the amount of lateral flow also increased (Figure 3c).

When we considered the sampling time with the simulated flow results, it confirmed that the sampling times were acceptable to represent the different river water conditions before and after rainfall. According to the simulating results, in Event 1, the total flow was almost zero at the before-rainfall sampling time. However, at the after-rainfall sampling time, surface flow was zero while $7.5 \mathrm{~mm}$ of lateral flow and $0.26 \mathrm{~mm}$ of ground water flow were estimated through the SWAT model. Before-rainfall sampling in Event 2 showed similar results with that in Event 1 . Total surface flow was zero, as were the others. On the other hand, the simulated results of the SWAT model estimated almost zero discharge at an after-rainfall sampling time in Event 2. This result implied that the amount of rainfall in Event 2 was not significant enough to change water level in the river. Table 3 compares lateral flow and ground water before and after rainfall in both Events. It showed that each sampling represents different water condition. Before-rainfall sampling in both Events showed similar water conditions for total runoff including surface, lateral, and ground water flow at almost zero. The after-rainfall sampling in Event 1 was estimated to have a higher level of lateral $(7.52 \mathrm{~mm})$ and groundwater flow $(0.26 \mathrm{~mm})$ than the level of that in Event 2 (lateral flow: $1.93 \mathrm{~mm}$, ground water flow: $0.01 \mathrm{~mm}$ ). 

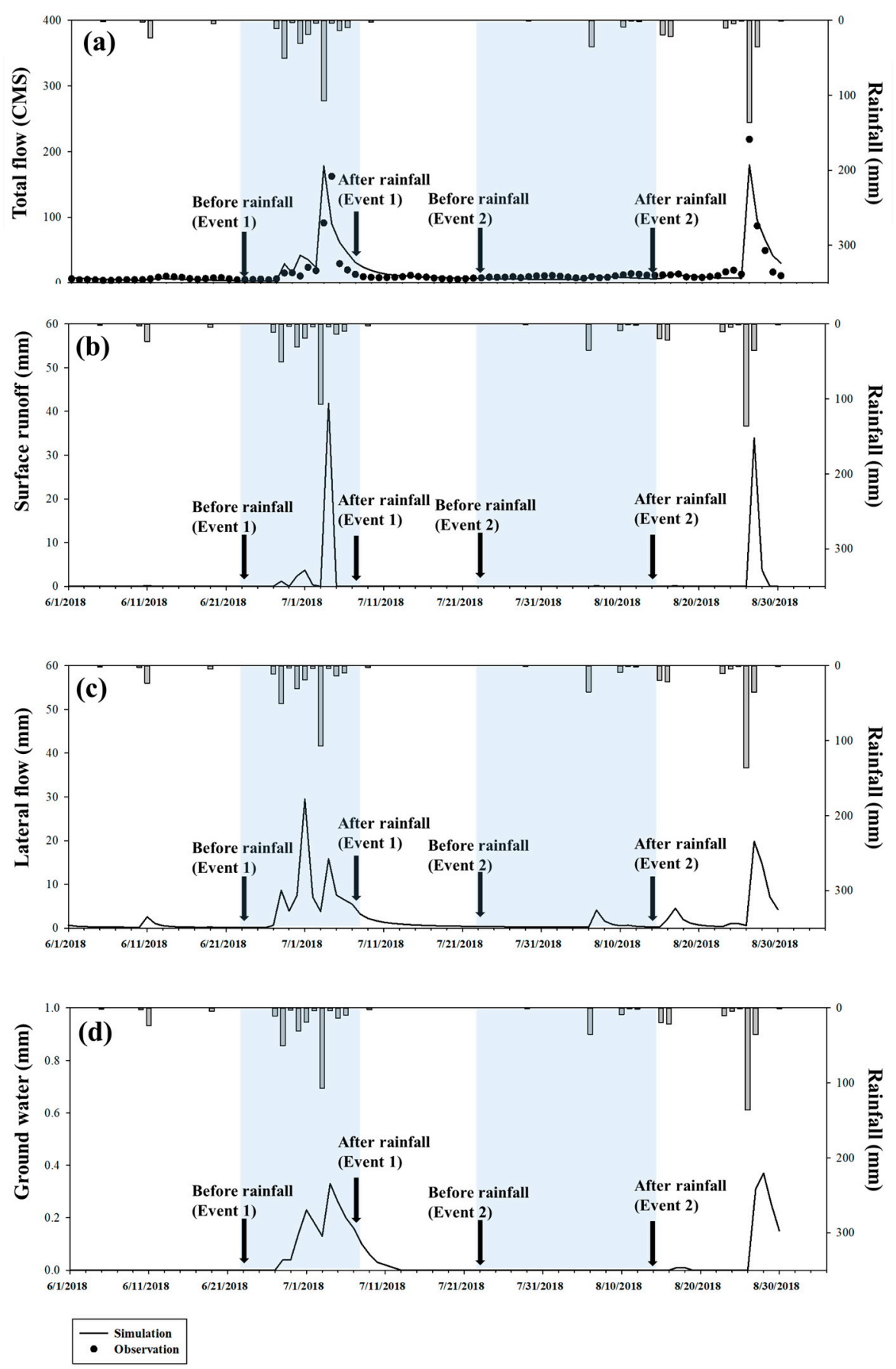

Figure 3. Simulated water flows by soil and water assessment tool (SWAT) model; (a) total flow, (b) surface runoff, (c) lateral flow, and (d) ground water.

Table 2. Characteristics of rainfall events.

\begin{tabular}{ccc}
\hline & Event 1 & Event 2 \\
\hline Rainfall Duration (hour) & 118 & 14 \\
Rainfall (mm) & 254 & 47.2 \\
Maximum rainfall intensity $(\mathrm{mm} / \mathrm{hr})$ & 15.9 & 11.2 \\
Date & $2018-06-29 \sim 2018-07-07$ & $2018-07-25 \sim 2018-08-13$ \\
Surface runoff $(\mathrm{mm})$ & 49.45 & 0.11 \\
Lateral flow $(\mathrm{mm})$ & 102.2 & 12.98 \\
Ground water $(\mathrm{mm})$ & 1.87 & 0 \\
\hline
\end{tabular}


Table 3. Lateral and ground water flow in Event 1 and Event 2.

\begin{tabular}{ccccc}
\hline & \multicolumn{2}{c}{ Event 1 } & \multicolumn{2}{c}{ Event 2 } \\
\hline & Lateral flow $(\mathrm{mm})$ & Ground flow $(\mathrm{mm})$ & Lateral flow $(\mathrm{mm})$ & Ground flow $(\mathrm{mm})$ \\
\hline Before rainfall & 0.09 & 0.00 & 0.35 & 0.00 \\
\hline After rainfall & 7.52 & 0.26 & 1.93 & 0.01 \\
\hline
\end{tabular}

\subsection{Water Characteristics}

Water characteristics of samples between Event 1 and Event 2 were measured in terms of DOC and conductivity (Table 4). DOC concentrations of midstream before rainfall in both Events were the highest among the samples. Since Taewha River flows through Ulsan City, the sampling point at midstream included more organic matter coming from the city than the upstream point that was surrounded by farmland (Figure 1). Conductivity of samples increased with the water flow due to the effect of seawater. However, after heavy rainfall in Event 1, water characteristics of the samples changed. DOC values of samples were higher than that of samples before rainfall, and they were not reduced along the river. In addition, conductivity decreased significantly in each sample. These water analysis results are linked to the SWAT model results that can track a source of organic matter and a water flow in the river. Heavy rainfall can increase DOC concentration because it flushes DOC adsorbed on aggregated surfaces and concentrated in subsoil [38]. Thus, the increased lateral flow after rainfall (7.52 mm in Table 2) in Event 1 significantly influenced the increase of DOC concentration in each sampling site. The decrease of conductivity and the increase of DOC along the river are also related to the changed water flow after heavy rainfall [39]. The increased water flow by rainfall diluted the ion concentration and caused the decrease of conductivity. The increase of DOC with water flow showed the flushing of DOC that was generated by rainfall.

Table 4. Water characteristics of sampling points $(n=3)$.

\begin{tabular}{cccccccc}
\hline & & & Event 1 & & \multicolumn{3}{c}{ Event 2 } \\
\hline & & Up & Mid & Down & Up & Mid & Down \\
\hline \multirow{3}{*}{$\begin{array}{c}\text { DOC } \\
(\mathrm{mg} \mathrm{C/L})\end{array}$} & Before & 1.61 & 2.16 & 0.78 & 2.00 & 2.50 & 1.90 \\
& rainfall & $( \pm 0.5)$ & $( \pm 1.0)$ & $( \pm 0.7)$ & $( \pm 0.7)$ & $( \pm 1.0)$ & $( \pm 0.4)$ \\
\cline { 2 - 8 } & After & 3.70 & 4.03 & 5.29 & 2.97 & 3.16 & 2.80 \\
& rainfall & $( \pm 1.2)$ & $( \pm 0.8)$ & $( \pm 1.2)$ & $( \pm 1.0)$ & $( \pm 0.8)$ & $( \pm 0.6)$ \\
\hline \multirow{3}{*}{$\begin{array}{c}\text { Conductivity } \\
(\mu \mathrm{S} / \mathrm{cm})\end{array}$} & Before & 301 & 5048 & 25480 & 218 & 803 & 27310 \\
& rainfall & $( \pm 20)$ & $( \pm 25)$ & $( \pm 10)$ & $( \pm 14)$ & $( \pm 16)$ & $( \pm 10)$ \\
\cline { 2 - 8 } & After & 146 & 169 & 405 & 207 & 412 & 21000 \\
& rainfall & $( \pm 13)$ & $( \pm 8)$ & $( \pm 11)$ & $( \pm 15)$ & $( \pm 10)$ & $( \pm 10)$ \\
\hline
\end{tabular}

Up: upstream, Mid: midstream, and Down: Downstream.

Event 2 showed different patterns of water characteristics compared to the patterns of that in Event 1 . The DOC concentration after rainfall in each sampling site did not increase as much as in Event 1 . It seems that the low lateral flow in Event 2 could not drive the flushing of DOC from soil due to the small amount of rainfall. The conductivity value increased from 207 to $21,000 \mu \mathrm{S} / \mathrm{cm}$ along the river; these results indicated that the rainfall did not affect the water characteristics of samples in the river. It is also connected to the amount of water flow, and this was estimated by SWAT model. Event 2 only had $40 \mathrm{~mm}$ of rainfall, and that was almost two times smaller than the amount of rainfall in Event 1 (Figure 3). Therefore, the smaller water flow in Event 2 could not dilute the ion concentration significantly. 


\subsection{Organic Matter Characterization}

\subsubsection{Molecular Weight (MW) Distribution}

Molecular weight distribution of DOM in two Events was measured by using HPLC-SEC with a UV detector (Figure 4). DOMs in upstream, midstream, and downstream showed similar molecular weight ranges from 580 to $1200 \mathrm{Da}$ before rainfall in Event 1 (Figure 4a). However, MW distributions of DOM in three sampling points after rainfall were still similar to each other. Their MW ranges shifted towards the large end, and the amount of molecules increased. In addition, the UV intensity of organic matter in upstream was the lowest while that of sample from downstream showed the highest after rainfall (Figure 3b). These results could be linked to water flow after rainfall. Since the SWAT model in this study simulated $7.52 \mathrm{~mm}$ of lateral flow after rainfall in Event 1 (Table 2), it could be considered that the new organic matter, which had large MW and high UV absorbance, was transported by the lateral flow after rainfall.
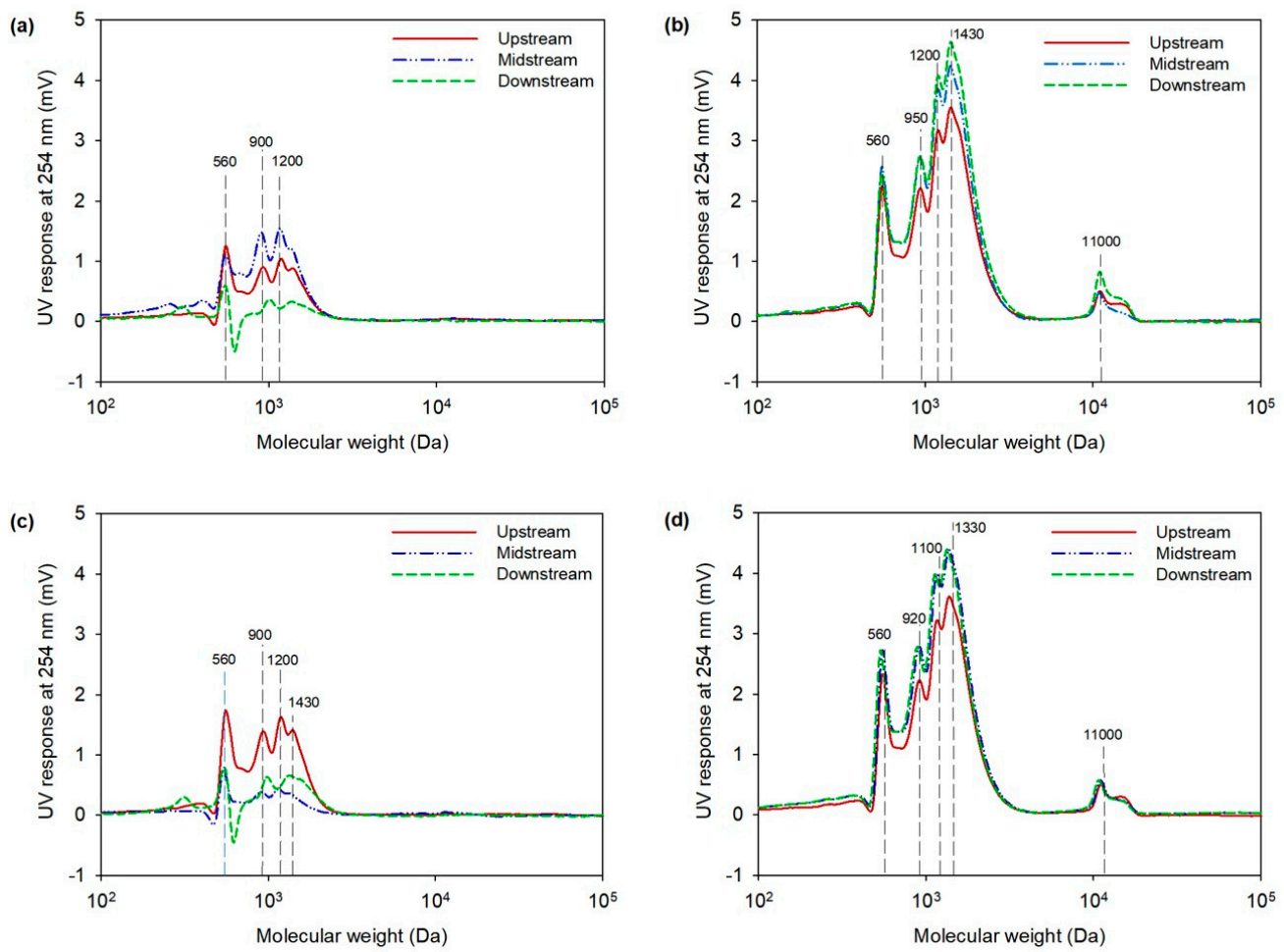

Figure 4. Molecular weight distribution of dissolved organic matter (DOMs) at each sampling points. (a) Before rainfall in Event 1, (b) after rainfall in Event 1, (c) before rainfall in Event 2, (d) after rainfall in Event 2.

In Event 2, the molecular weight distribution of DOMs in every sampling point had a similar range from 560 to 1430 Da before rainfall (Figure 4c). The chromatograms of organic matter after rainfall showed similar patterns after rainfall in Event 1. The UV intensity of samples increased and high MW of organic matter $(\sim 11,000 \mathrm{Da})$ was detected (Figure $4 \mathrm{~d})$. When comparing the MW distribution results after rainfall in Event 1 and Event 2, the results were similar to each other. Although the simulated lateral flow in Event 1 (7.52 $\mathrm{mm})$ was higher than in Event $2(1.93 \mathrm{~mm})$, the amount of the flow did not influence the MW distribution. However, these results implied that the lateral flow could transport the DOM having large MW and high UV absorbance after rainfall.

\subsubsection{EEM}

Using EEM, fluorescent organic matter in each Event was compared before and after rainfall (Figure 5). The EEM results were used for calculating fluorescence regional integration (FRI) values. 
Figure 6a depicts the organic matter composition at three sampling points during Event 1 . The portion of fulvic acid-like organics decreased, but the portions of tryptophan- and tyrosine-like protein increased along the river. Tryptophan-like and tyrosine-like protein are involved in a protein-like component [40]. Thus, the increase in the portion of protein-like components indicated that the microbial activity increased along the river. Since fulvic acid-like organics generally originated from the forest ecosystem, the high portion of these organics in upper stream could be inferred to be a result of this origin. However, after rainfall, every sample showed similar organic matter composition, which included $62.3 \%$ of humic acid-like organics, $27.6 \%$ of fulvic acid-like organics, $2.4 \%$ of tyrosine-like protein, and $7.7 \%$ of tryptophan-like protein (Figure $6 \mathrm{a}$ ). When comparing the FRI results between before and after rainfall at Event 1, the results implied that ecological processes in the river did not influence organic molecules. At Event 2, FRI results were similar to the results at Event 1 (Figure 6b). The molecular compositions were different among the sampling points before rainfall, but similar molecular compositions were shown in the FRI result of three sampling points after rainfall. The reason could be that new organic matter was added after rainfall, and it passed through the river in a relatively short time that was not enough to decompose the organic matter.
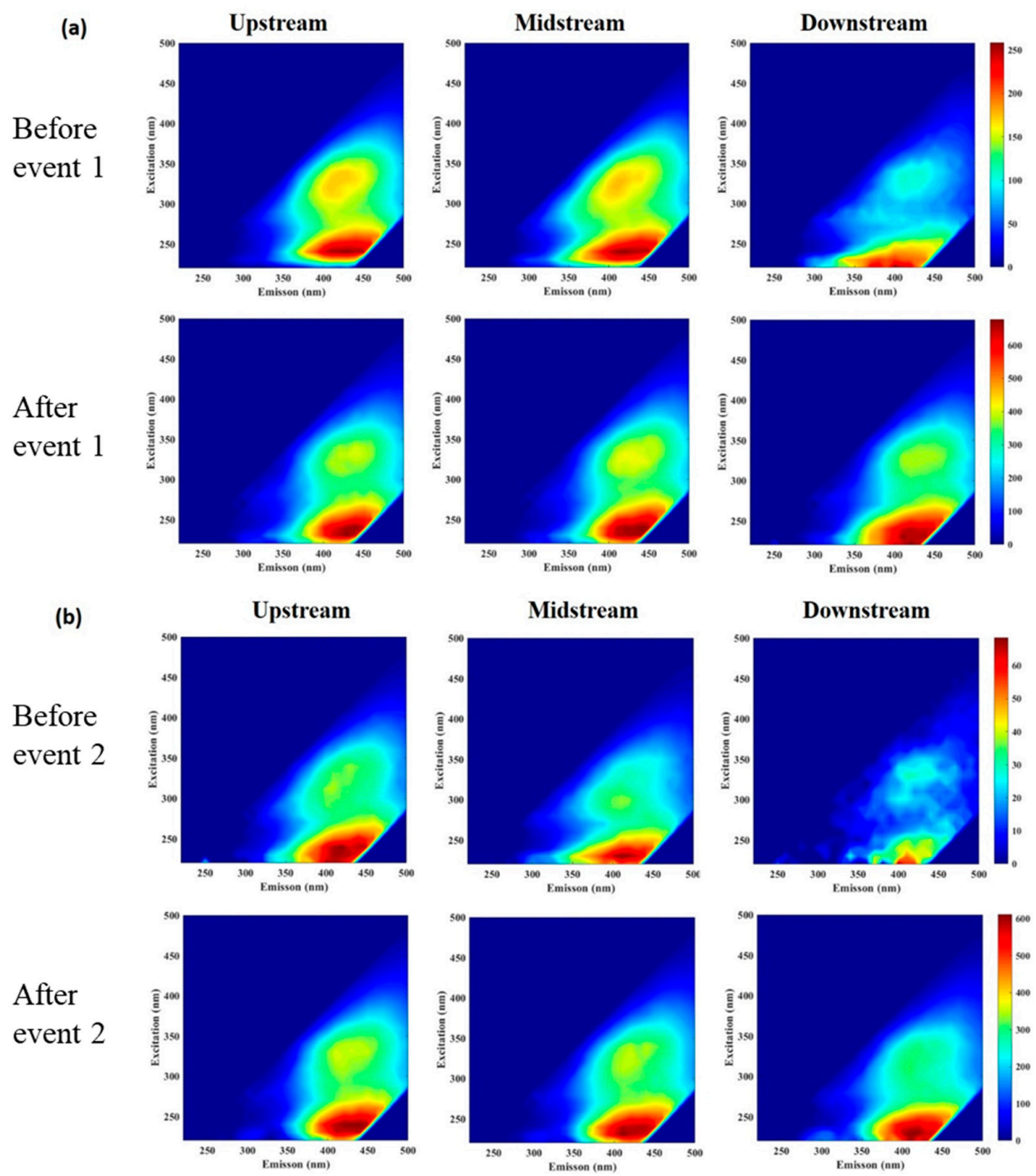

Figure 5. EEMs of samples based on their sampling points: (a) EEM results in Event 1; (b) EEM results in Event 2. 

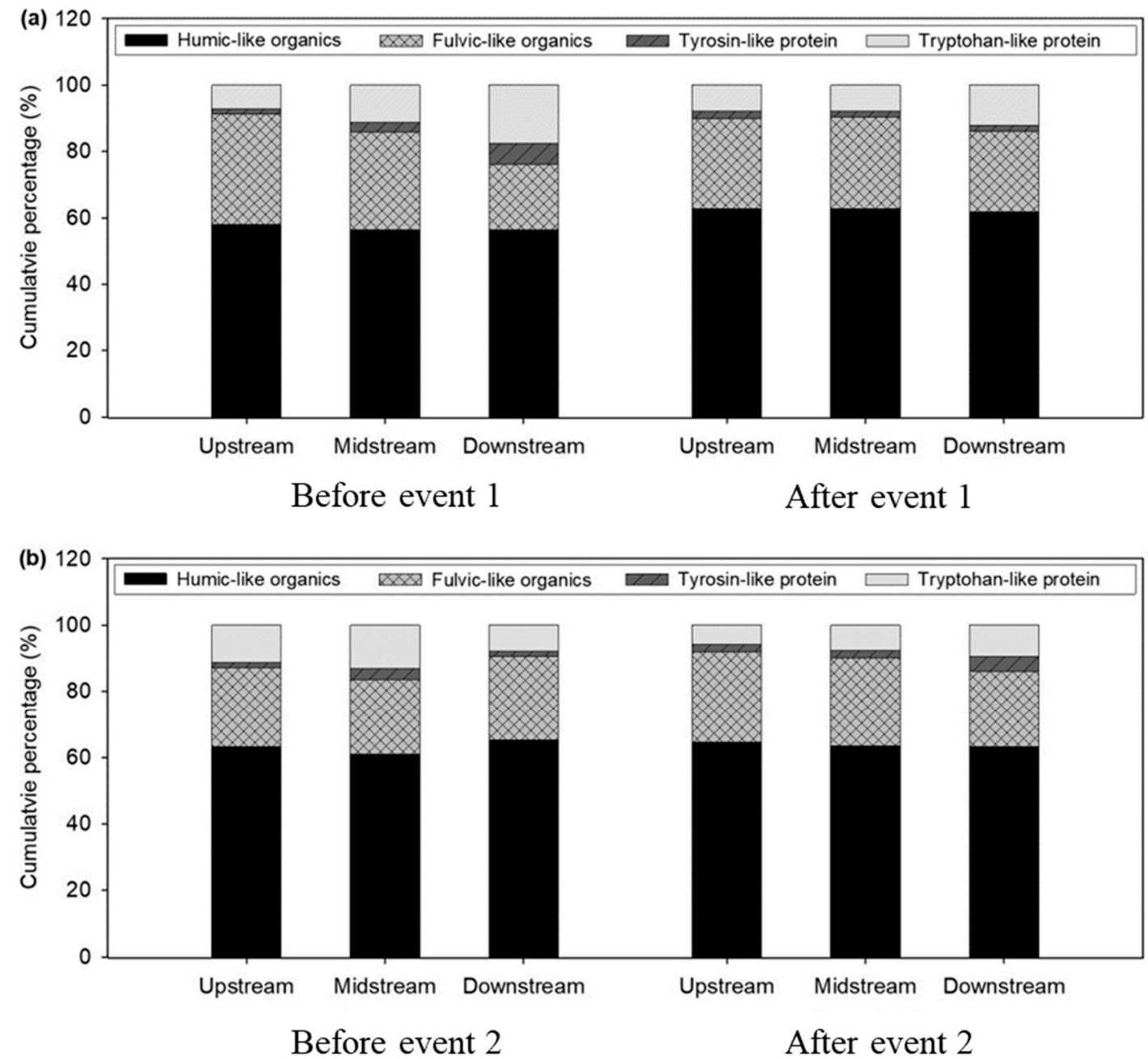

Figure 6. Distribution of fluorescence regional integration (FRI) of organic matters at each sampling point in (a) Event 1 and (b) Event 2.

\subsubsection{XAD}

Hydrophobicity of the organic matter was estimated by using XAD-8 and XAD-4 resins (Figure 7). The hydrophobic fraction is considered a humic substances including humic and fulvic acids, and the hydrophilic fraction is referred to as microbial products such as polysaccharides and amides $[9,41]$. The transphilic fraction contains hydroxyl, sugar, and sulfonic acids [42]. At Event 1, hydrophobic and hydrophilic portions increased but transphilic portions decreased along the river water flow before rainfall (Figure 7a). This result showed that microorganisms decomposed the organic matter in the river. The transphilic fractions could decrease when the microorganisms used the fraction as nutrient sources. Then, hydrophilic fraction would increase by enhancing microbial activities. However, after rainfall, hydrophobic properties of organic matter were not changed along the river water flow. These results connected to the results in Section 3.3.1. in terms of the new organic matter transported by the lateral flow and the relatively short retention time for a biological decomposition. 

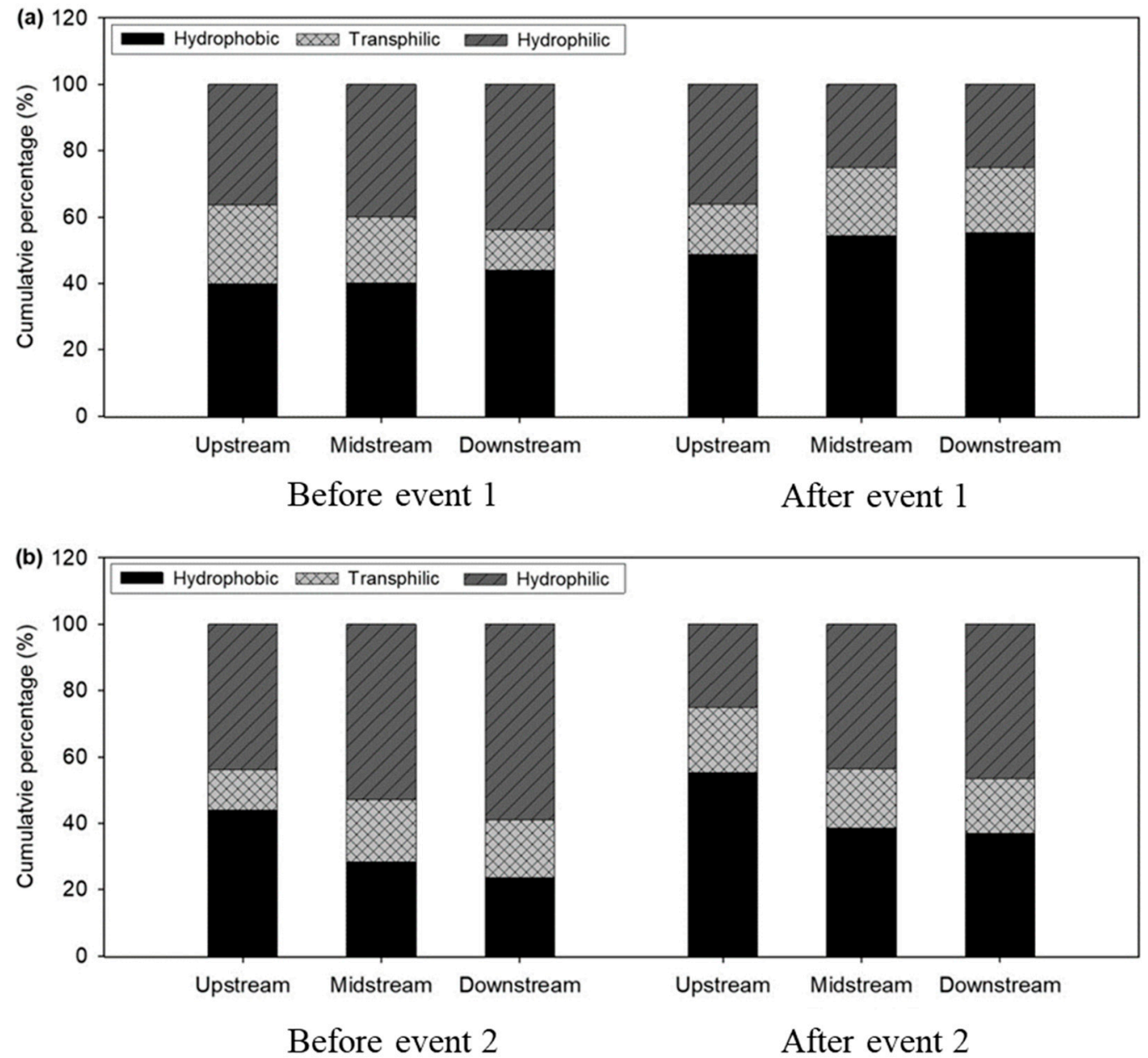

Figure 7. Hydrophobic (HPO), Transphilic (TPI), and Hydrophilic (HPI) composition of DOMs at each sampling point in (a) Event 1 and (b) Event 2.

\subsubsection{Orbit Trap Mass}

DOMs in each sampling point were analyzed by Orbitrap mass spectrometry to obtain the molecular-level characteristics of the samples (Figure 8). Identified formulae were classified into four groups: (1) $\mathrm{CHO}$, (2) $\mathrm{CHON}$, (3) CHOS, and (4) CHONS. Figure 8 shows that $\mathrm{CHON}$ is the most abundant in every sample (30 45\%). When comparing the element compositions between before and after rainfall in both Events, CHONS formulae before rainfall in every Event decreased at the downstream point (Up: $35.2 \%$ > Mid: $33.9 \%$ > Down: $21.6 \%$ in Event 1, UP: $31.5 \% \cong$ Mid: $31.2 \%>$ Down: $21.7 \%$ in Event 2 ) while the formulae after rainfall remained relatively stable (Up: $32.4 \%$ > Mid: $29.6 \% \cong$ Down: $29.0 \%$ in Event 1, UP: $25.3 \%$ < Mid: $28.4 \%$ > Down: $22.4 \%$ in Event 2). Although the amount of rainfall in Event 1 was much higher than Event 2, the element compositions of DOM after rainfall between two Events were similar. 

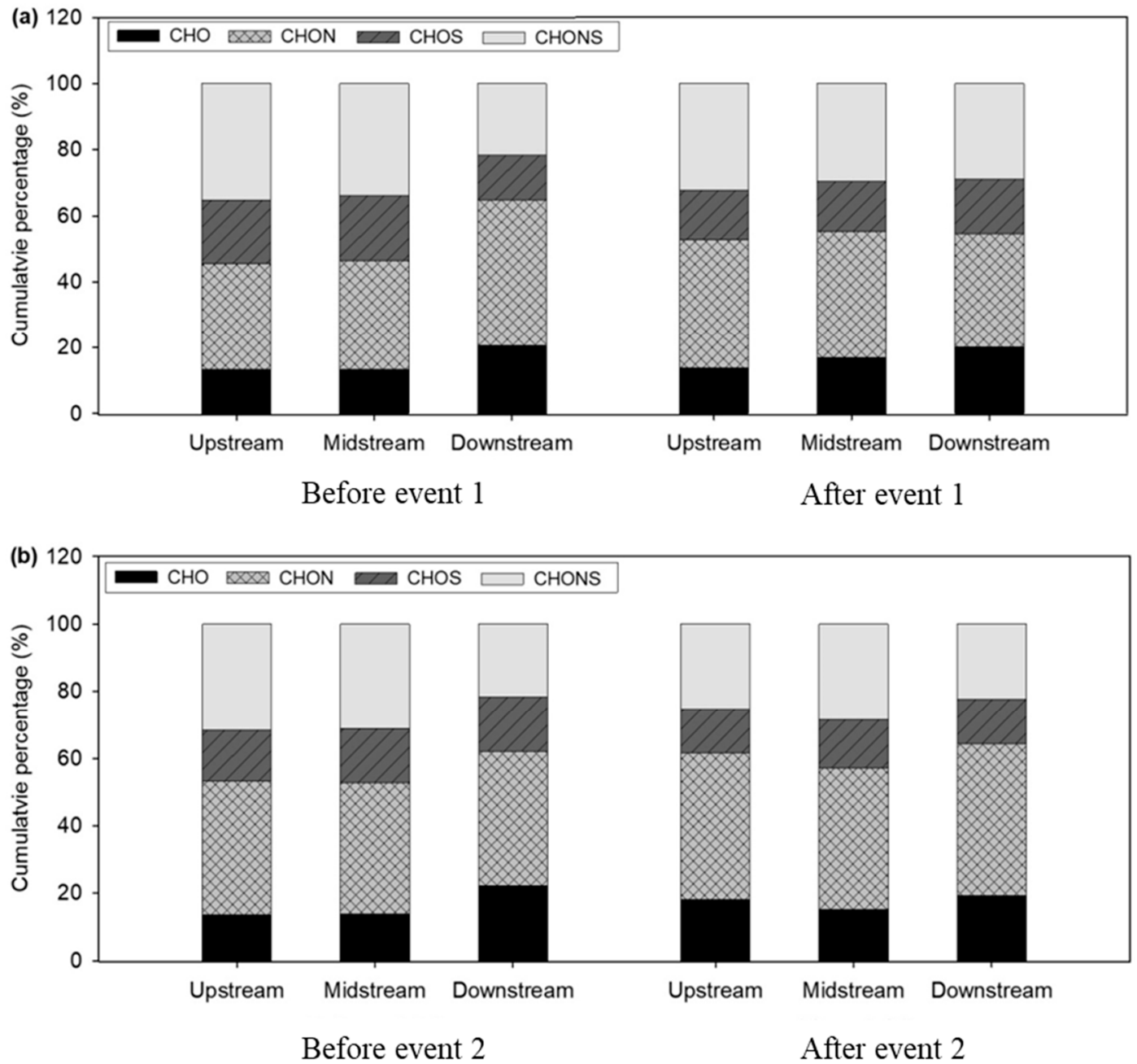

Figure 8. Element compositions of DOMs at each sampling point in (a) Event 1 and (b) Event 2.

Van Krevelen diagrams for $\mathrm{CHON}$ formulae, which were the major group in the samples, were used for comparison. According to Kim et al., [34] some major biomolecular components are identified by using the van Krevelen diagram that is described with atomic ratios of $\mathrm{O} / \mathrm{C}$ and $\mathrm{H} / \mathrm{C}$. The diagram is divided into several regions for specific organic matters: (1) lipids $(0.01<\mathrm{O} / \mathrm{C}<0.1,1.5<\mathrm{H} / \mathrm{C}$ $<2.0)$, (2) tannins $(0.65<\mathrm{O} / \mathrm{C}<0.85,0.75<\mathrm{H} / \mathrm{C}<1.5)$, (3) $\operatorname{lignin}(0.1<\mathrm{O} / \mathrm{C}<0.65,0.75<\mathrm{H} / \mathrm{C}<$ 1.5), (4) protein $(0.1<\mathrm{O} / \mathrm{C}<0.65,1.5<\mathrm{H} / \mathrm{C}<2.3)$, (5) carbohydrates $(0.65<\mathrm{O} / \mathrm{C}<1.0,1.5<\mathrm{H} / \mathrm{C}<$ 2.5), (6) condensed aromatic structures $(0.01<\mathrm{O} / \mathrm{C}<0.65,0.25<\mathrm{H} / \mathrm{C}<0.75)$, and (7) unsaturated hydrocarbons $(0.01<\mathrm{O} / \mathrm{C}<0.1,0.75<\mathrm{H} / \mathrm{C}<1.5)$.

All of identified formulae of DOMs in Event 1 and Event 2 were distributed over all regions (Figure 9). However, the cumulative counts for the formulae indicate the differences of molecular compositions among the samples. In Event 1, before-rainfall samples showed lipids increasing along the river, while lignin existed in every sampling site after rainfall. In Event 2, condensed hydrocarbons and lignin were detected upstream and midstream before rainfall, and lipids were downstream like the result in Event 1. However, lignin was in every sample after rainfall in both Events. The results described that new organic matter was added after rainfall, and it passed through the river without chemical changes. It also supported the previous results that lateral flow including new organic matter could influence organic matter characteristics after rainfall. 
(a)
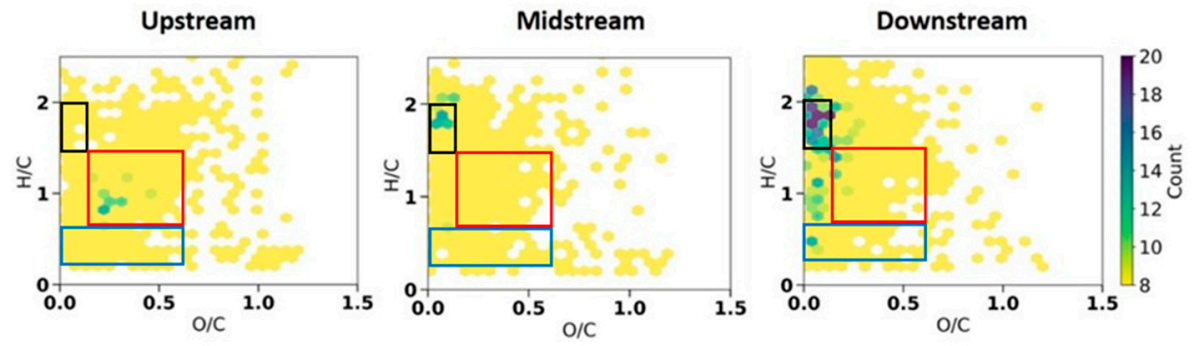

Before event 1
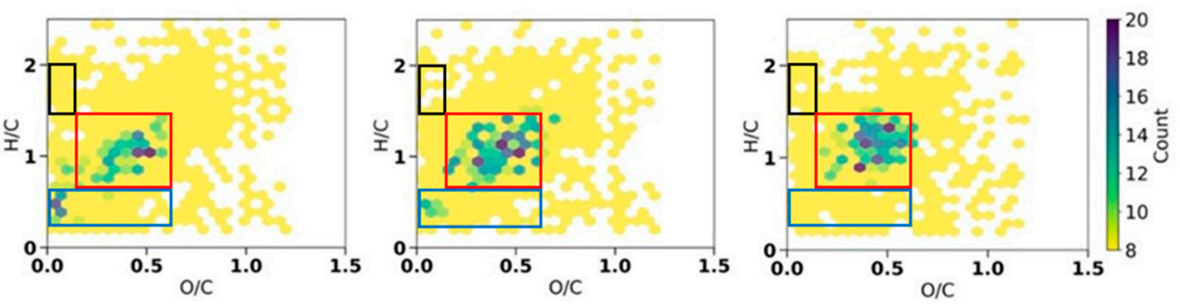

(b)

Upstream

Before event 2
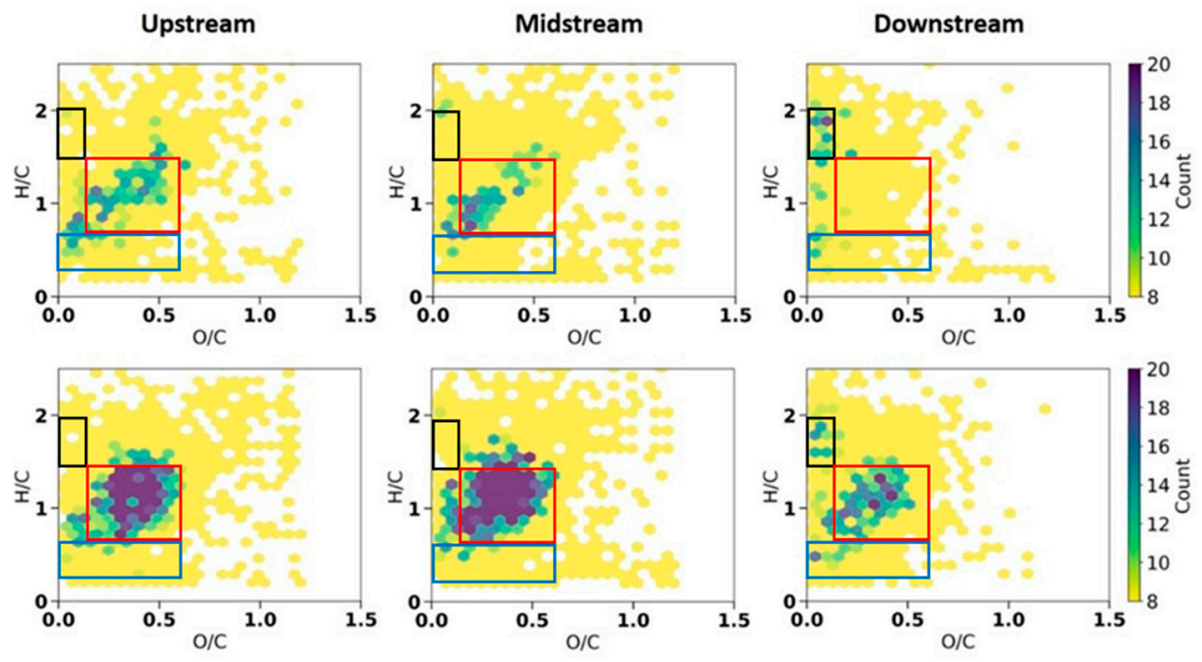

$$
\begin{aligned}
& \square \text { Lipid } \\
& \square \text { Lignin } \\
& \square \text { Condensed hydrocarbons }
\end{aligned}
$$

Figure 9. Van Krevelen diagrams of $\mathrm{CHON}$ formulae of DOMs at each sampling point in (a) Event 1 and (b) Event 2.

\subsection{Discussion}

The SWAT results described the hydrological components before and after rainfall. Generally, a SWAT model is used for the interpretation of hydrological components in a large-scale watershed [35]. This model requires several hydrological parameters; however, certain parameters can exhibit errors. The SWAT model, used in this study, was developed by the data set (2013-2015); as a result, the model showed acceptable simulation performance (i.e., NSE > 0.5) [37]. As a result, we could interpret the DOM movement behavior in the river depending on surface runoff, lateral flow, and ground water. A previous study shows that the SWAT model has also been used to analyze the effect of the hydrological components in a watershed [22].

Generally, the characterization of DOM for identifying a source was conducted by analytical experiments. A sample was taken from a sampling point and analyzed after pretreatment steps [43]; from the results, the source of DOM was identified. However, the limitation of this approach is that it is difficult to reflect the hydrological property of the sampling points. DOM characteristics vary depending on the weather conditions. The concentrations of DOM and microbial organic matter increase during the dry season and decrease int he wet season [44]. It followed similar results from the 
previous results regarding to DOM in lateral flow. Inamdar et al. reported that DOC concentration was in agreement with the rise in groundwater elevations after heavy raining [45]. In the paper, they mentioned that DOM in near-surface soil water influenced on the increase of DOC concentration in a stream. As well, Kari et al. explained that the high DOC concentration at high discharge relates with the increased lateral flow because the stored decomposing plant material in soil can be released when they are connected with lateral flow [46]. Therefore, organic matter characterization requires comprehensive information.

In this study, using the SWAT model, we found that the lateral flow increased after a heavy rainfall. The organic matter characterization results in this study also supported the results. The DOC concentration and conductivity increased from upstream to downstream before rainfall. However, after heavy rainfall, riverine water flow influenced the downstream resulting in decreased conductivity. We also found a change in molecular characteristics before and after rainfall. The molecular size and amount of humic substances, including humic and fulvic acids, increased after rainfall. It might be due to the increase of the lateral flow as the flow contains high portion of humic substances $[47,48]$. Vance and David reported that forest floor leachates contained monosaccharides, polyphenols, and fulvic acids [47]. Their study showed $60 \%$ of hydrophobic fraction of the leachates, but our samples contained approximately $45 \%$ to $50 \%$ of hydrophobic fraction because our samples were taken from a river.

A high portion of lignin in the sample, after rainfall, was found by orbitrap mass spectrometry. Sleighter and Hatcher exhibited similar results through the analysis of DOM in a swamp [49]. Stenson et al. mentioned that lignin is the major precursor to riverine DOM [50]. These results, including those in our study, indicated that DOM in lateral flow is one of the major sources of DOM in a river. This study used two rainfall events to analyze DOM change before and after the rainfall events. Two rainfall events might not be enough to draw the exact conclusion, even though a high consistency is found in our study. Accordingly, the further research will be required for better understanding of the fate and transport DOM in the stream by implementing additional rainfall monitoring.

\section{Conclusions}

This study characterized DOM in a river before and after rainfall, and the analyzed results were interpreted as matching the data with the hydraulic condition of the river. Dissolved organic matter characterization was conducted via molecular size distribution, hydrophobicity, fluorescence excitation and emission, and molecular composition. The SWAT model estimated hydrological components including total runoff, surface flow, lateral flow, and ground water. The simulated water flow from the SWAT model clearly described the change of organic matter characteristics after rainfall. Major findings of this study are as follows:

(1) After rainfall, a large amount of terrestrial DOM flushed into the river. We found that the terrestrial DOM characteristics in the river were maintained until the DOM passed through the river completely.

(2) DOM properties were analyzed by the hydrologic components from the SWAT model. Herein, we found that lateral flow could be the major source of the new organic matter after rainfall.

(3) According to the orbitrap mass spectrometer analysis, the lateral flow transported a large amount of lignin into the river.

Author Contributions: S.B. and H.L. collected water quality data and conducted the simulation of SWAT model. J.P. and K.H.C. designed the experiments and drew the conclusion.

Funding: This work was supported by National Institute of Environmental Research funded by Ministry of Environment [NIER-2018-03-01-005] and by the Korea Environment Industry \& Technology Institute (KEITI) through "The Chemical Accident Prevention Technology Development Project", funded by Korea Ministry of Environment (MOE) (No. 2016001970001).

Conflicts of Interest: The authors declare no conflict of interest. 


\section{References}

1. Volk, C.J.; Volk, C.B.; Kaplan, L.A. Chemical composition of biodegradable dissolved organic matter in streamwater. Limnol. Oceanogr. 1997, 42, 39-44. [CrossRef]

2. Kalbitz, K.; Wennrich, R. Mobilization of heavy metals and arsenic in polluted wetland soils and its dependence on dissolved organic matter. Sci. Total Environ. 1998, 209, 27-39. [CrossRef]

3. Park, J.; Cho, K.H.; Lee, E.; Lee, S.; Cho, J. Sorption of pharmaceuticals to soil organic matter in a constructed wetland by electrostatic interaction. Sci. Total Environ. 2018, 635, 1345-1350. [CrossRef] [PubMed]

4. Leenheer, J.A.; Croué, J.-P. Peer reviewed: Characterizing aquatic dissolved organic matter. Environ. Sci. Technol. 2003, 37, 18A-26A. [CrossRef] [PubMed]

5. Park, J.; Chon, K.; Lee, E.; Cho, J. Developing a large-volume preparative method using a handmade HPLC column to fractionate dissolved organic matter. Desalin. Water Treat. 2017, 67, 97-104. [CrossRef]

6. Guo, L.; Lehner, J.K.; White, D.M.; Garland, D.S. Heterogeneity of natural organic matter from the Chena River, Alaska. Water Res. 2003, 37, 1015-1022. [CrossRef]

7. Reyes, T.G.; Crisosto, J.M. Characterization of Dissolved Organic Matter in River Water by Conventional Methods and Direct Sample Analysis-Time of Flight-Mass Spectrometry. J. Chem. 2016, 2016, 1537370. [CrossRef]

8. Nebbioso, A.; Piccolo, A. Molecular characterization of dissolved organic matter (DOM): A critical review. Anal. Bioanal. Chem. 2013, 405, 109-124. [CrossRef]

9. Imai, A.; Fukushima, T.; Matsushige, K.; Hwan Kim, Y. Fractionation and characterization of dissolved organic matter in a shallow eutrophic lake, its inflowing rivers, and other organic matter sources. Water Res. 2001, 35, 4019-4028. [CrossRef]

10. Haitzer, M.; Höss, S.; Traunspurger, W.; Steinberg, C. Effects of dissolved organic matter (DOM) on the bioconcentration of organic chemicals in aquatic organisms-A review. Chemosphere 1998, 37, 1335-1362. [CrossRef]

11. Park, J.; Choi, M.; Cho, J.; Chon, K. Transformation of dissolved organic matter in a constructed wetland: A molecular-level composition analysis using pyrolysis-gas chromatography mass spectrometry. Environ. Eng. Res. 2018, 23, 390-396. [CrossRef]

12. Chon, K.; Chon, K.; Cho, J. Characterization of size fractionated dissolved organic matter from river water and wastewater effluent using preparative high performance size exclusion chromatography. Org. Geochem. 2017, 103, 105-112. [CrossRef]

13. Ward, N.D.; Richey, J.E.; Keil, R.G. Temporal variation in river nutrient and dissolved lignin phenol concentrations and the impact of storm events on nutrient loading to Hood Canal, Washington, USA. Biogeochemistry 2012, 111, 629-645. [CrossRef]

14. Inamdar, S.; Singh, S.; Dutta, S.; Levia, D.; Mitchell, M.; Scott, D.; Bais, H.; McHale, P. Fluorescence characteristics and sources of dissolved organic matter for stream water during storm events in a forested mid-Atlantic watershed. J. Geophys. Res. Biogeosci. 2011, 116, G03043. [CrossRef]

15. Nguyen, H.V.-M.; Hur, J.; Shin, H.-S. Changes in Spectroscopic and Molecular Weight Characteristics of Dissolved Organic Matter in a River During a Storm Event. Water Air Soil Pollut. 2010, 212, 395-406. [CrossRef]

16. Park, J.H.; Lee, J.H.; Kang, S.Y.; Kim, S.Y. Hydroclimatic controls on dissolved organic matter (DOM) characteristics and implications for trace metal transport in Hwangryong River Watershed, Korea, during a summer monsoon period. Hydrol. Process. 2007, 21, 3025-3034. [CrossRef]

17. Zhang, X.; Srinivasan, R.; Debele, B.; Hao, F. Runoff simulation of the headwaters of the yellow river using The SWAT model with three snowmelt algorithms 1. JAWRA J. Am. Water Resour. Assoc. 2008, 44, 48-61. [CrossRef]

18. Thompson, J.; Sørenson, H.R.; Gavin, H.; Refsgaard, A. Application of the coupled MIKE SHE/MIKE 11 modelling system to a lowland wet grassland in southeast England. J. Hydrol. 2004, 293, 151-179. [CrossRef]

19. Hundecha, Y.; Bárdossy, A. Modeling of the effect of land use changes on the runoff generation of a river basin through parameter regionalization of a watershed model. J. Hydrol. 2004, 292, 281-295. [CrossRef]

20. Kim, M.; Boithias, L.; Cho, K.H.; Silvera, N.; Thammahacksa, C.; Latsachack, K.; Rochelle-Newall, E.; Sengtaheuanghoung, O.; Pierret, A.; Pachepsky, Y.A. Hydrological modeling of Fecal Indicator Bacteria in a tropical mountain catchment. Water Res. 2017, 119, 102-113. [CrossRef] 
21. Cho, K.H.; Pachepsky, Y.A.; Kim, J.H.; Kim, J.-W.; Park, M.-H. The modified SWAT model for predicting fecal coliforms in the Wachusett Reservoir Watershed, USA. Water Res. 2012, 46, 4750-4760. [CrossRef] [PubMed]

22. Abbaspour, K.C.; Yang, J.; Maximov, I.; Siber, R.; Bogner, K.; Mieleitner, J.; Zobrist, J.; Srinivasan, R. Modelling hydrology and water quality in the pre-alpine/alpine Thur watershed using SWAT. J. Hydrol. 2007, 333, 413-430. [CrossRef]

23. Neitsch, S.L.; Arnold, J.G.; Kiniry, J.R.; Williams, J.R. Soil and Water Assessment Tool Theoretical Documentation Version 2009; Texas Water Resources Institute: College Station, TX, USA, 2011.

24. Pyo, J.; Pachepsky, Y.A.; Kim, M.; Baek, S.-S.; Lee, H.; Cha, Y.; Park, Y.; Cho, K.H. Simulating seasonal variability of phytoplankton in stream water using the modified SWAT model. Environ. Model. Softw. 2017. [CrossRef]

25. Santhi, C.; Arnold, J.G.; Williams, J.R.; Dugas, W.A.; Srinivasan, R.; Hauck, L.M. validation of the swat model on a large RWER basin with point and nonpoint sources 1. JAWRA J. Am. Water Resour. Assoc. 2001, 37, 1169-1188. [CrossRef]

26. Rostamian, R.; Jaleh, A.; Afyuni, M.; Mousavi, S.F.; Heidarpour, M.; Jalalian, A.; Abbaspour, K.C. Application of a SWAT model for estimating runoff and sediment in two mountainous basins in central Iran. Hydrol. Sci. J. 2008, 53, 977-988. [CrossRef]

27. Zhang, Q.; Li, L. Development and application of an integrated surface runoff and groundwater flow model for a catchment of Lake Taihu watershed, China. Quat. Int. 2009, 208, 102-108. [CrossRef]

28. Srinivasan, R.; Zhang, X.; Arnold, J. SWAT ungauged: Hydrological budget and crop yield predictions in the Upper Mississippi River Basin. Trans. Asabe 2010, 53, 1533-1546. [CrossRef]

29. Ligaray, M.; Baek, S.S.; Kwon, H.-O.; Choi, S.-D.; Cho, K.H. Watershed-scale modeling on the fate and transport of polycyclic aromatic hydrocarbons (PAHs). J. Hazard. Mater. 2016, 320, 442-457. [CrossRef] [PubMed]

30. Guo, L.; Lu, M.; Li, Q.; Zhang, J.; Zong, Y.; She, Z. Three-dimensional fluorescence excitation-emission matrix (EEM) spectroscopy with regional integration analysis for assessing waste sludge hydrolysis treated with multi-enzyme and thermophilic bacteria. Bioresour. Technol. 2014, 171, 22-28. [CrossRef] [PubMed]

31. Park, N.; Choi, Y.; Kim, D.; Kim, K.; Jeon, J. Prioritization of highly exposable pharmaceuticals via a suspect/non-target screening approach: A case study for Yeongsan River, Korea. Sci. Total Environ. 2018, 639, 570-579. [CrossRef]

32. Kujawinski, E.B.; Behn, M.D. Automated analysis of electrospray ionization Fourier transform ion cyclotron resonance mass spectra of natural organic matter. Anal. Chem. 2006, 78, 4363-4373. [CrossRef]

33. Phungsai, P.; Kurisu, F.; Kasuga, I.; Furumai, H. Molecular characterization of low molecular weight dissolved organic matter in water reclamation processes using Orbitrap mass spectrometry. Water Res. 2016, 100, 526-536. [CrossRef]

34. Kim, S.; Kramer, R.W.; Hatcher, P.G. Graphical method for analysis of ultrahigh-resolution broadband mass spectra of natural organic matter, the van Krevelen diagram. Anal. Chem. 2003, 75, 5336-5344. [CrossRef] [PubMed]

35. Spruill, C.A.; Workman, S.R.; Taraba, J.L. Simulation of daily and monthly stream discharge from small watersheds using the SWAT model. Trans. ASAE 2000, 43, 1431. [CrossRef]

36. Hargreaves, G.H.; Samani, Z.A. Reference crop evapotranspiration from temperature. Appl. Eng. Agric. 1985, 1, 96-99. [CrossRef]

37. Moriasi, D.N.; Arnold, J.G.; Van Liew, M.W.; Bingner, R.L.; Harmel, R.D.; Veith, T.L. Model evaluation guidelines for systematic quantification of accuracy in watershed simulations. Trans. Asabe 2007, 50, 885-900. [CrossRef]

38. Kalbitz, K.; Solinger, S.; Park, J.-H.; Michalzik, B.; Matzner, E. Controls on the dynamics of dissolved organic matter in soils: A review. Soil Sci. 2000, 165, 277-304. [CrossRef]

39. Li, F.; Yuasa, A.; Muraki, Y.; Matsui, Y. Impacts of a heavy storm of rain upon dissolved and particulate organic C, N and P in the main river of a vegetation-rich basin area in Japan. Sci. Total Environ. 2005, 345, 99-113. [CrossRef] [PubMed]

40. Hudson, N.; Baker, A.; Reynolds, D. Fluorescence analysis of dissolved organic matter in natural, waste and polluted waters-A review. River Res. Appl. 2007, 23, 631-649. [CrossRef]

41. Park, N.; Kwon, B.; Kim, S.-D.; Cho, J. Characterizations of the colloidal and microbial organic matters with respect to membrane foulants. J. Membr. Sci. 2006, 275, 29-36. [CrossRef] 
42. Lee, S.; Cho, J.; Elimelech, M. Combined influence of natural organic matter (NOM) and colloidal particles on nanofiltration membrane fouling. J. Membr. Sci. 2005, 262, 27-41. [CrossRef]

43. Meng, F.; Huang, G.; Yang, X.; Li, Z.; Li, J.; Cao, J.; Sun, L. Identifying the sources and fate of anthropogenically impacted dissolved organic matter (DOM) in urbanized rivers. Water Res. 2013, 47, 5027-5039. [CrossRef]

44. Elifantz, H.; Kautsky, L.; Mor-Yosef, M.; Tarchitzky, J.; Bar-Tal, A.; Chen, Y.; Minz, D. Microbial activity and organic matter dynamics during 4 years of irrigation with treated wastewater. Microb. Ecol. 2011, 62, 973-981. [CrossRef] [PubMed]

45. Inamdar, S.P.; O'Leary, N.; Mitchell, M.J.; Riley, J.T. The impact of storm events on solute exports from a glaciated forested watershed in western New York, USA. Hydrol. Process. 2006, 20, 3423-3439. [CrossRef]

46. Austnes, K.; Evans, C.D.; Eliot-Laize, C.; Naden, P.S.; Old, G.H. Effects of storm events on mobilisation and in-stream processing of dissolved organic matter (DOM) in a Welsh peatland catchment. Biogeochemistry 2010, 99, 157-173. [CrossRef]

47. Vance, G.F.; David, M.B. Chemical characteristics and acidity of soluble organic substances from a northern hardwood forest floor, central Maine, USA. Geochim. Cosmochim. Acta 1991, 55, 3611-3625. [CrossRef]

48. Jardine, P.M.; Wilson, G.V.; McCarthy, J.F.; Luxmoore, R.J.; Taylor, D.L.; Zelazny, L.W. Hydrogeochemical processes controlling the transport of dissolved organic carbon through a forested hillslope. J. Contam. Hydrol. 1990, 6, 3-19. [CrossRef]

49. Sleighter, R.L.; Hatcher, P.G. The application of electrospray ionization coupled to ultrahigh resolution mass spectrometry for the molecular characterization of natural organic matter. J. Mass Spectrom. 2007, 42, 559-574. [CrossRef]

50. Schnitzer, M. Humic substances: Chemistry and reactions. In Developments in Soil Science; Elsevier: Amsterdam, The Netherlands, 1978; pp. 1-64.

(C) 2019 by the authors. Licensee MDPI, Basel, Switzerland. This article is an open access article distributed under the terms and conditions of the Creative Commons Attribution (CC BY) license (http:/ / creativecommons.org/licenses/by/4.0/). 